Received 27 December 2019; accepted 4 April 2020.

Available online 30 April 2020

\title{
Integration of Energy Efficiency measures and Renewable Energy technologies as an Approach to Sustainable development in Egypt
}

\section{Salwa Abd El Monem El Gindi}

Lecturer at October University for Modern Sciences and Arts

salwagindi@hotmail.com

\begin{abstract}
Energy demand has been increasing worldwide and the building sector represents a large percentage of global Energy consumption. This is directly related to increasing global warming.

In Egypt, electricity consumption is increasing rapidly due to the rapid population growth, urbanization, economical development and increase in comfort levels. To solve the Energy problems, efforts need to be concentrated on the supply side, and the demand side as well. Energy efficiency is becoming an integral and important part of solving the Energy problem at the demand side. On the other hand, Renewable Energy technologies are promising as a solution at the supply side. Thus there is a need for integrated, adaptive, approach to reach the optimal combination of applying energy efficiency measures and Renewable Energy sources.
\end{abstract}

In this paper the energy related policies of Egypt have been presented. The present status of renewable energy utilization in Egypt has been discussed as well. The research introduces and examines the effect of combining Energy Efficiency measures with photovoltaic rooftop application in an air-conditioned office building in Egypt. Annual Energy reductions and Annual energy production due to the PV roof top installation was calculated by means of Energy Plus, a reliable Energy simulation software.The energy requirements for cooling, and lighting was evaluated as well.

It was proven that Reductions in Annual Energy Consumption reached about $48 \%$ due to applying Energy Effeciency measures. The Annual electricity production due to the installation of $900 \mathrm{~m} 2 \mathrm{PV}$ Panels on the building roof coverd about $40 \%$ from the building Energy consumption. This demonstrates that it is technically possible to meet more than $60 \%$ reductions in building Energy consumption with the proper combination between Energy Efficiency measures and RE sources.

KEYWORDS: Energy Efficiency, Renewable Energy, Building Integrated Photovoltaics.

\section{INTRODUCTION}

As a result of the country's development, urban expansion and changing in people's life style, the energy consumption and consequently the electricity consumption has been rapidly increasing.

This increase in electricity consumption has increased the demands on the power sector, which mainly relies on fossil fuel. Thus there is an urgent need to formulate a comprehensive and integrated strategy to solve the Energy problem that should include the supply side, the demand side and the energy efficiency techniques employed on both sides. Efforts have been done by the Government to support 
sustainable and integrated Energy strategies by promoting generation of electricity from Renewable Energy sources. Yet these efforts has to be supported by decreasing consumption at the demand side. Promoting the application of Energy efficiency measures alongside with enhancing Renewable energy production and application can greatly contribute in solving Energy problems and ensure Energy security. A supply/demand strategy will formulate a solution for the energy problem and will provide an adequate balance that is expected to be more sustainable on the long run. In order to moderate the Energy requirements and ensure the Energy balance for the long run, enhancing Energy Efficiency and promoting RE integration in buildings represent a cost-effective technical and financial solution. There is a big opportunity to promote Energy Efficiency and not only depending on allocating resources to increase the supply side. Also by proper integration of RE applications, the energy problems in Egypt could be adequately solved. In order to assess the current problem, it is important to reflect the current status of the power sector in Egypt.

\begin{tabular}{|ll|}
\hline Nomenclature & \\
\hline RE & Renewable Energy \\
PV & Photovoltaics \\
\hline
\end{tabular}

\section{ELECTRICITY CONSUMPTION AND PRODUCTION IN EGYPT}

Egypt's net electricity consumption, increased in less than a decade by 54\% (from 1988 till 1997, (http://www.eia.doe.gov/emeulintemationallegypt.html), with an annual increase in electricity consumption between 6-7\% (http://www.sis.gov.eg.). The built environment consumes about $52 \%$ of the gross national production of produced energy. In 1998 Egypt was ranked the 29th country among 125 countries assessed in electricity consumption; and the second major in Africa (after South Africa). In 2014/2015 the Peak Load reached 28,015 MW compared to 26,140 MW in 2013/2014 with a percentage rate of increase of about 7.2\% While in 2016/2017, the Peak Load reached 29,400 MW compared to 29,200 MW in 2015/2016 at a variation rate of about $0.7 \%$ (Fig.1).

Figure (1) Peak load curve 2015/2014-2016/2017.

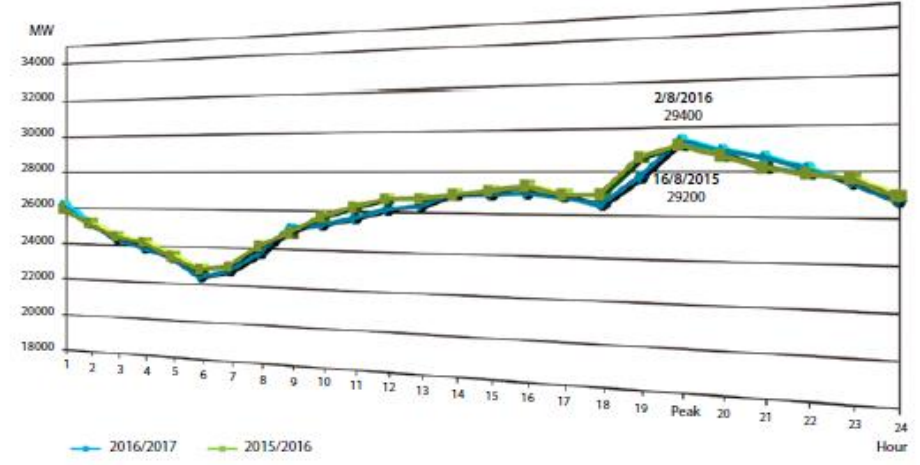

Source:Egyptian Electricity Holding Company report 2016/2017.

In 2017, the installed capacity reached 45,008 MW compared to 38,857 MW in 2016 at a variation rate of $15.8 \%$ (fig.2).

Production of electricity in Egypt depends mostly on fossil fuels while only $6 \%$ of electricity is produced from hydro sources and $2 \%$ from Renewables (Wind and Solar). 
The average growth rate of the peak load is $2.2 \%$ \& installed capacity is $10 \%$ per year during the period from 2012/2013 till 2016/2017.(EEHC 2016/2017)

Figure (2) Peak load and installed capacity.

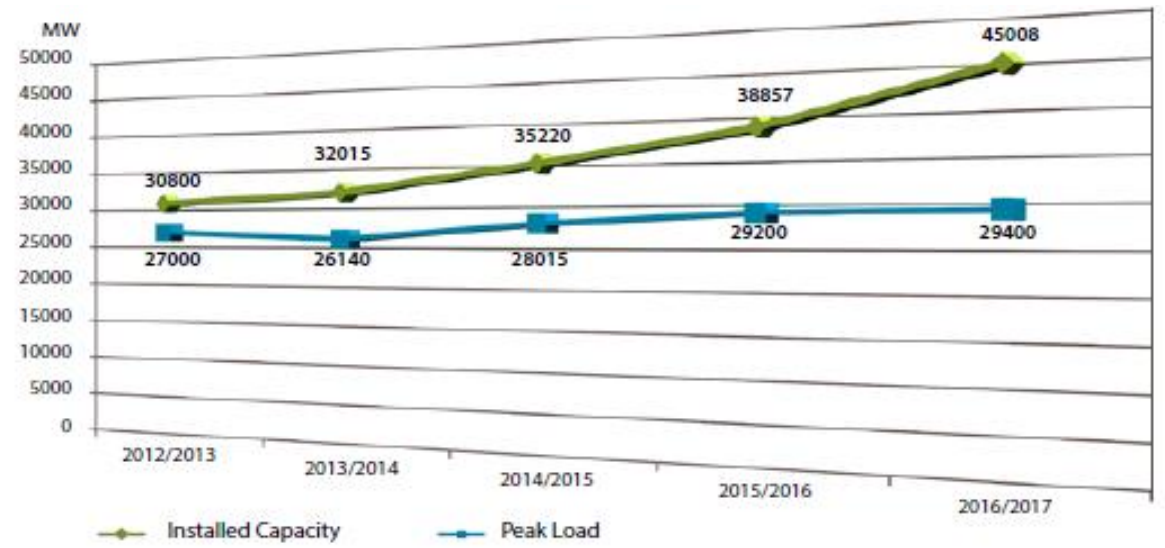

Source: Egyptian Electricity Holding Company Annual report. $(2016,2017)$

Figure (3) Installed Capacity by type of generation percentage.

\section{Installed Capacity by Type \%}

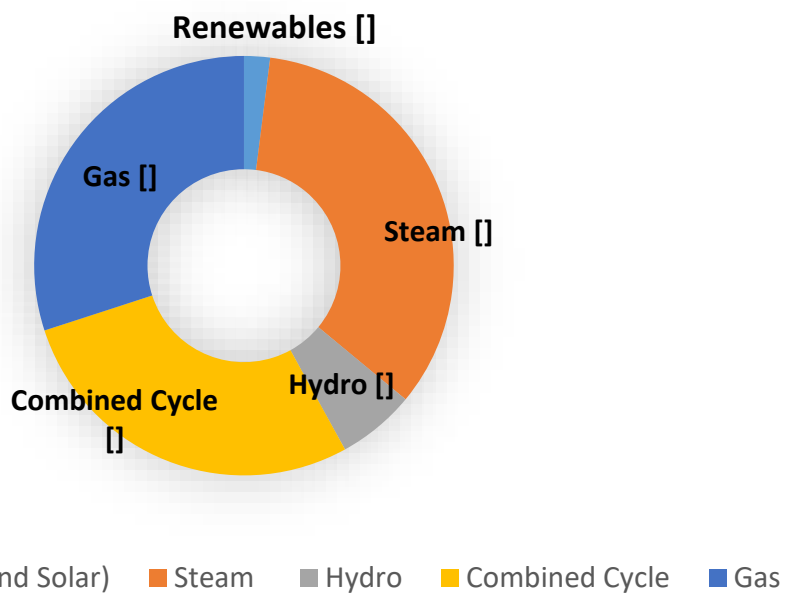

Source:Egyptian Electricity Holding CompanyAnnual report(2016,2017)

Electricity utilization in building sector has grown rapidly, with annual growth rate about $7 \%$ in 2002 . This was attributed to the increase in urban population, growing income and comfort levels.

Figures (4) illustrates the Energy consumption in various building types, it can be noticed that both the commercial and residential buildings consume about $47 \%$ of the electricity consumption .

As shown in figure (5), air conditioning and lighting account for over two thirds of electricity consumption in commercial and public sectors. 
Table (1) Electricity consumption percentage in different sectors.

\begin{tabular}{|ll|}
\hline Sector & $37.8 \%$ \\
\hline Residential & $7.7 \%$ \\
\hline Commercial and others & $3.9 \%$ \\
\hline Agriculture & $34.8 \%$ \\
\hline Industry & $6.3 \%$ \\
\hline Public lighting & $5.3 \%$ \\
\hline Governmental & $4.1 \%$ \\
\hline Public utilities
\end{tabular}

Source:Abdin.A. et al.(2006)

Figure (4) Electricity consumption in different sectors

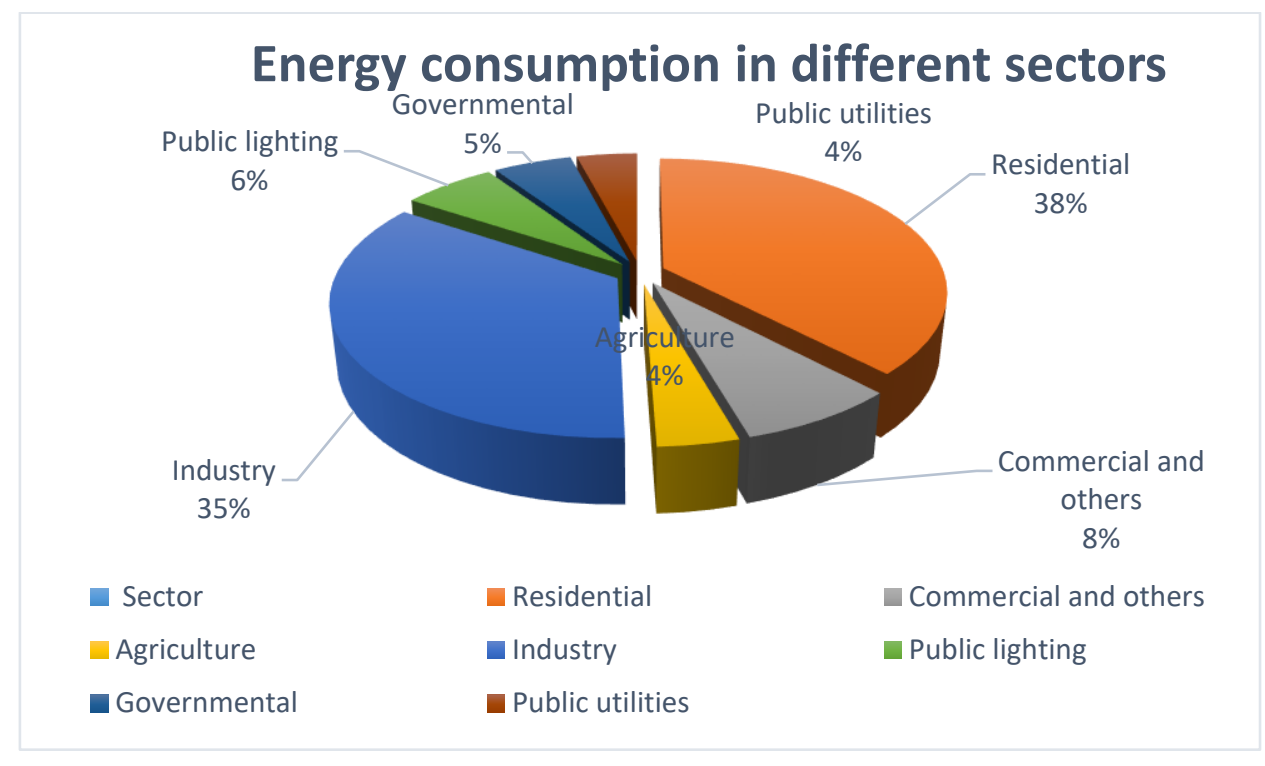

Source:Abdin.A. et al.. (2006)

Figure(5) Electricity consumption in commercial sector.

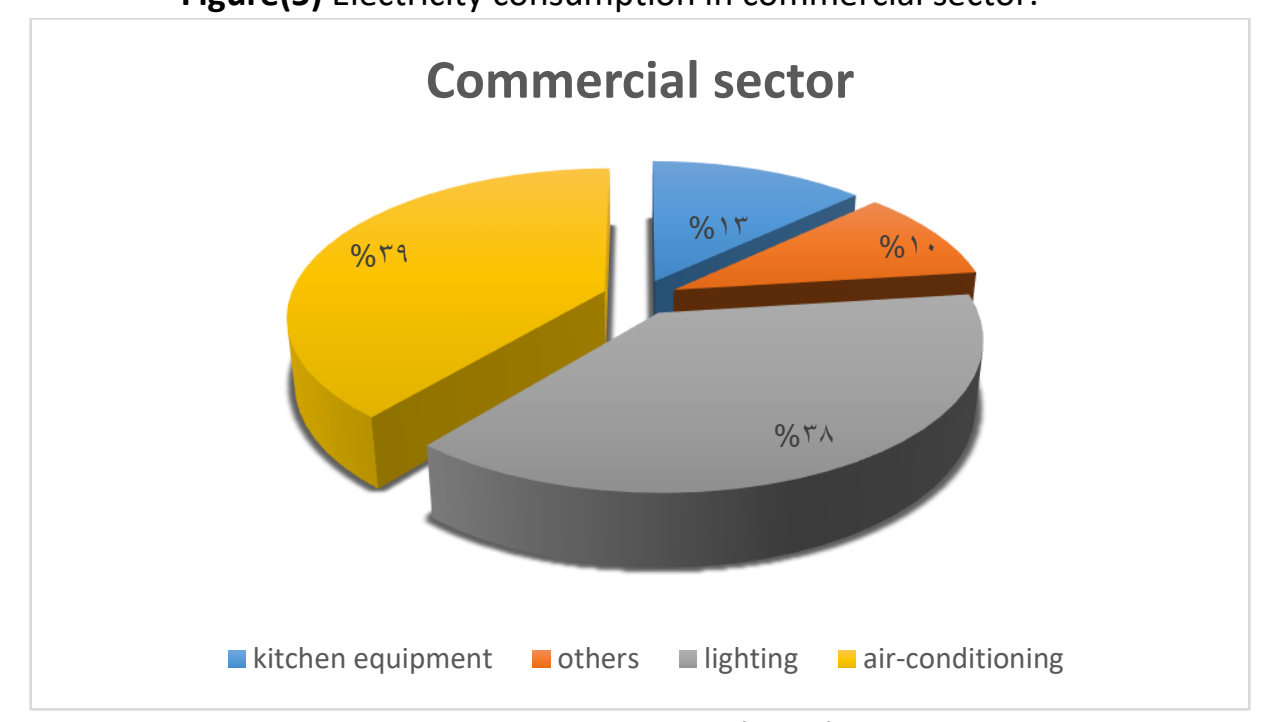

Source:Abdin.A. et al.. (2006) 
Many countries have adobted and fostered Energy Efficiency policies effectively which resulted in a noticeable reduction in their Energy consumption.

There is a strong need to focus more efforts on environmental policies and to properly push for energy efficiency promotion in all sectors.

\section{ENERGY EFFECIENCY IN OFFICE BUILDINGS.}

Over the last years, Sustainability has become one of the core public ideas of the current age. Since buildings and particularly office buildings are large energy consumers, the concept of sustaining office building has become the focus of interest amongst governments.

There is a chance to decrease energy use, conserve resources and make considerable progress toward achieving energy independence and reduced global warming emissions by applying energy efficiency measures.

As the climate of Egypt, imposes very hot and dry summers, in combination with the urban heat island found in big cities like Cairo, there is extended use of airconditioning in office buildings. Large amounts of electricity could have been avoided by a more considerable use and consequently reducing the carbon footprint of buildings.

A large number of energy un-efficient office building stock exist which have a deep effect on national resources consumption. This suggests that office buildings needs an integrated approach for implementation of Energy Efficiency measures to improve their performance.

\subsection{Energy Conservation Technologies in Office Buildings}

Table (2) Energy conservation technologies in office Buildings.

\begin{tabular}{|l|l|}
\hline $\begin{array}{l}\text { Heating and cooling } \\
\text { demand reduction-( } \\
\text { Demand Side Management) }\end{array}$ & $\begin{array}{l}\text { Building fabric insulation. } \\
\text { Windows (i.e. multiple glazing, low-E coatings, } \\
\text { shading systems, etc.), Cool roof and cool } \\
\text { coatings, Air tightness, etc. }\end{array}$ \\
\hline $\begin{array}{l}\text { Low energy technologies, } \\
\text { Energy Efficient equipment. } \\
\text { (Demand Side } \\
\text { Management) }\end{array}$ & $\begin{array}{l}\text { Natural ventilation, Lighting, Efficient Controls, } \\
\text { Thermal storage, Energy efficient equipment } \\
\text { and appliances, Heat recovery, etc. }\end{array}$ \\
\hline $\begin{array}{l}\text { Renewable energy } \\
\text { technologies. (Supply Side } \\
\text { Management). }\end{array}$ & $\begin{array}{l}\text { Geothermal power systems, Solar thermal } \\
\text { systems, Solar PV/PVT systems, Biomass } \\
\text { systems, Efficient Electric system. }\end{array}$ \\
\hline $\begin{array}{l}\text { Human factors. } \\
\text { (Energy conservation } \\
\text { patterns) }\end{array}$ & $\begin{array}{l}\text { Occupancy regimes, Comfort requirements, } \\
\text { Occupant activities, Access to controls, } \\
\text { Management and maintenance, }\end{array}$ \\
\hline
\end{tabular}




\subsection{Incorporating Energy Saving Measures to Building Envelops}

In spite of the fact that the mechanical system and how it operates plays the most essential role in determining the energy efficiency of our buildings, the building envelope also has a large impact on gross energy consumption. Improving the energy efficiency of buildings is achieved by means of incorporating energy saving measures to building envelops.

\subsubsection{Wall Insulation.}

Wall insulation is important for heat retention in cool conditions, heat exclusion in warm conditions, and preventing the ingress of solar gains made by the absorption of radiation on the outside of the opaque wall.

External insulation protects the structure from solar gains made on the external surface of the building. Insulation material may be added to the inside or the outside surface, or by filling the cavities within the wall structure.(Baker,N.2009).

Figure(6) Options for external insulation of solid walls.
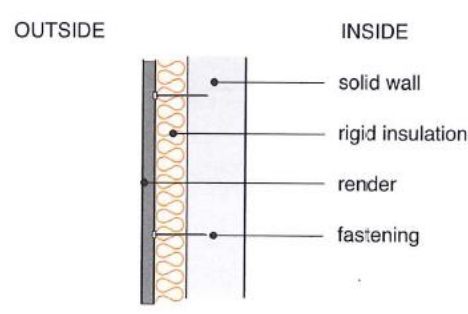

OPTION 1
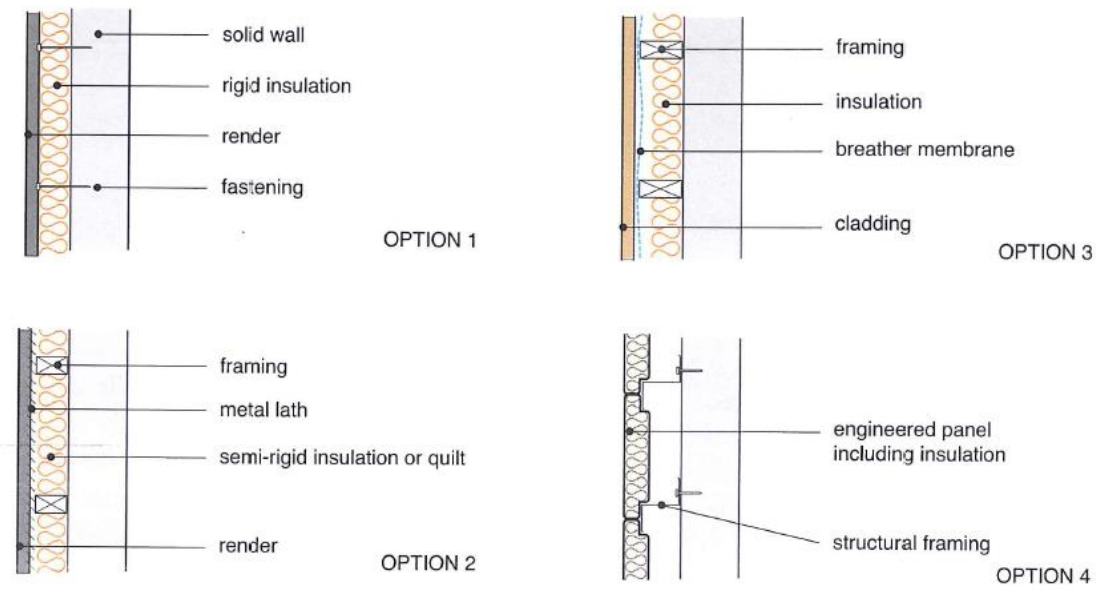

(Source: Baker,N.2009)

\subsubsection{Roofs}

The most effective method of reducing heat transfer through the roof is to lower the " $U$ " value of the roof by adding insulation. For buildings with large roof areas in proportion to floor area (single story buildings), consideration should be given both to insulating the roof and to reducing its absorption coefficient. (Baker,N.2009).

\subsubsection{Improving day light penetration through Glazing improvements}

Windows are the most energy- transmissive element in the Envelop. The kind of glass selected should give good visible light transmission for adequate daylighting, and have low solar heat transmission (Place et al., 1984). Single glazing conduct heat to the exterior and should be replaced with double glazing with air gap between glazing panels. In Double glazing, adding air gap between the glazing layers decreases the Uvalue. However, heat transfer between the two panes still takes place by radiation. 
Reducing heat transfer by radiation can be achieved by coating the surface of inner leaf that faces the cavity with low-Emissivity coating, This very thin(less than a wavelength of light) metallic, layer transmits short wavelengths(visible light)but acts as a poor emitter for long wave infra-red(IR) .(Baker,N.2009).

Figure (7) The mechanisms of energy transfer through glazing by conduction and convection

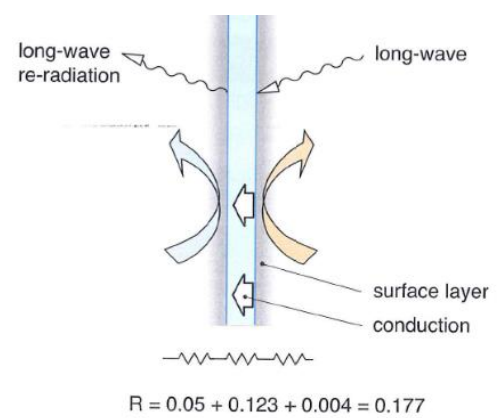

Source: Baker,N.2009.)

\section{RENEWABLE ENERGY}

Rapid depletion of fossil fuel reserves as well as climate change has driven the world towards RE sources which are abundant, and environmentally friendly.

Their technologies for power generation are, reliable, mature and cost effective. Previous research have indicated that the use of Renewable energies can cover most of the energy needs in a building, reducing its carbon footprint.(Vourdoubas,2018)

\subsection{Renewable Energy Status and Egyptian Energy Policy}

According to the NREA Annual Report 2018, the total installed capacity from renewable Sources reached $4100 \mathrm{MW}$, where Hydro power plants represents about $68 \%$ of total installed capacity from renewable Sources, while wind power represents $24 \%$, and Concentrated solar power represents $4 \%$. (Figure 8 )

The total Produced Energy from Renewables reached 15600 Million KWh, where 12850 Million KWh are produced from Hydro Power plants representing 83\%, 2200 Million KWh from Wind representing 14\%, 480 Million KWh from Concentrated solar power representing $3 \%$ and 0.3 Million KWh from Photovoltaics.(Figure 9).

The fuel saving reached 4600 Million Ton of Oil Equivalent and 8.4 Million Ton CO2 Emission Reduction. 
Figure (8). Total Installed Capacity Total installed Capacity MW

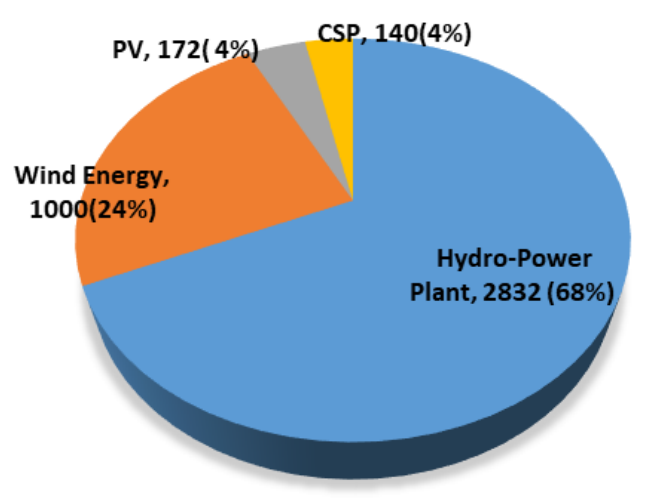

- Hydro-Power Plant $\quad$ Wind Energy $\quad$ PV $\quad$ CSP

Source: NREA Ministry of Electricity \&Renewable Energy

Annual Report 2018
Figure (9). Total Energy Produced

Total Energy Produced (Million KWh)

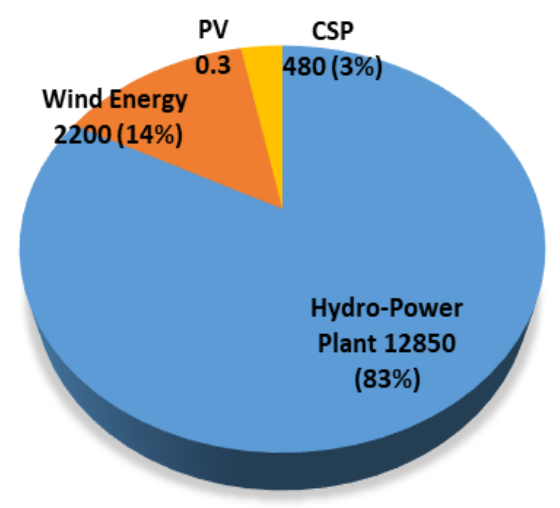

- Hydro-Power Plant w Wind Energy aPV $\square \mathrm{CSP}$

Source: NREA Ministry of Electricity \&Renewable Energy Annual Report 2018

\section{Egyptian strategy for renewable energy}

According to NREA 2018, Egypt is targeting to produce $20 \%$ of its total Energy production from Renewable Sources by 2022 as follows: $12 \%$ from Wind, $6 \%$ from Hydro-Power and 2\% from PV. Renewable Energy Strategy will be implemented through two integral paths as follows:

Governmental Projects (about 33\%from the total installed capacities) and Private Sector Projects (about 67\% from the total installed capacities).

Encouraging the participation of the private sector in renewable energy projects requires taking on several procedures including setting supportive policies and motivational technical and financial mechanisms.

Supportive policies has been adopted by the government to increase the private sector 's contribution in Renewable Energy projects. Among these policies are, applying Feed-in-tariff (Aug.2009), Competitive bids and issuing tenders internationally requesting private sector to supply power from wind energy projects, Third Party Access (June 2012) where Investors are allowed to build \&operate RE power plants to satisfy their electricity needs or to sell electricity to other consumers though the national grid. In Jan.2013, Egyptera Board approved to apply Net Metering system to encourage PV Roof Top systems implementation. In Sept.2013, Quota System was introduced, where heavy industries with large energy consumption will be obliged to produce a percentage of its electricity needs from RE sources starting from 2015. Financial incentives play an essential role in encouraging investors to utilize RE technologies that's why the government has adopted incentives policies such as exempting all Renewable Energy equipment from the customs duties.Several projects has been implemented or under preparation by the Ministry of Electricity \&Renewable Energy, NREA and the Private sector as well. 
Figure (10) Solar Energy Projects

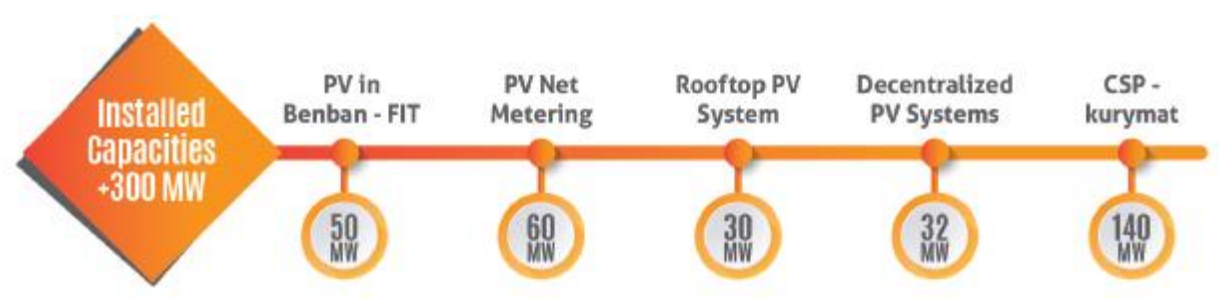

Source: NREA Annual report 2018

Figure (11) Projects under construction

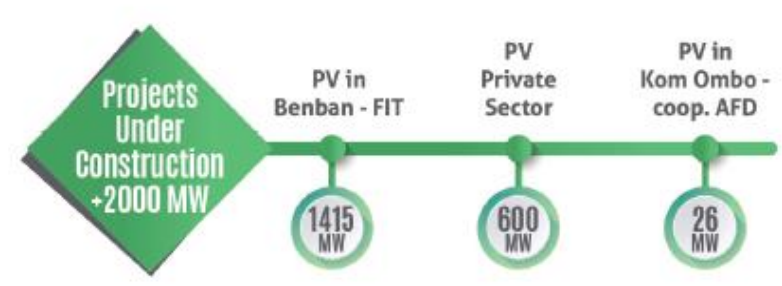

Source: NREA Annual report 2018

\section{SOLAR PV SYSTEMS APPLICATIONS}

Salem et al. have investigated building integrated photovoltaics applications in Mediterranean countries. The authors have stated that Mediterranean basin is characterized by high solar irradiance, at $7.5-8 \mathrm{kWh} / \mathrm{m} 2$ annually. They concluded that solar-PVs applied to commercial buildings, which mainly operate during the day, can cover most of their electricity demands. Biyik et al. have reported on building integrated photovoltaic systems (BIPV). The authors have stated that in the last decade, BIPVs have attracted an increasing interest and they are considered as a feasible technology to cover part of the electricity load in buildings. They have also examined the possibility of ventilating the solar-PV system in order to decrease the temperature of the panels and to increase their efficiency. Hayter et al. have reported on solar-PVs applications in buildings. The authors have examined the performance of three solar-PV systems, at $7 \mathrm{KWp}$ to $60 \mathrm{KWp}$, installed in three commercial buildings. They stated that these systems have reduced the electricity demands in the buildings. They suggested that solar-PV systems should be integrated into the building in its initial design phase. Tselepis investigated the PV market developments in Greece with reference to net-metering case studies. He analyzed two case studies presented for a commercial enterprise and a household He indicated the viability of the netmetering program.

\section{CASE STUDY}

A typical office building in Cairo,Egypt was simulated for its Energy consumption using Design Builder Simulation software.

In Fig.12 the modeled office building is shown. The main characteristics of the building and design conditions are reported in table 3. 
Figure (12) Case Study building.
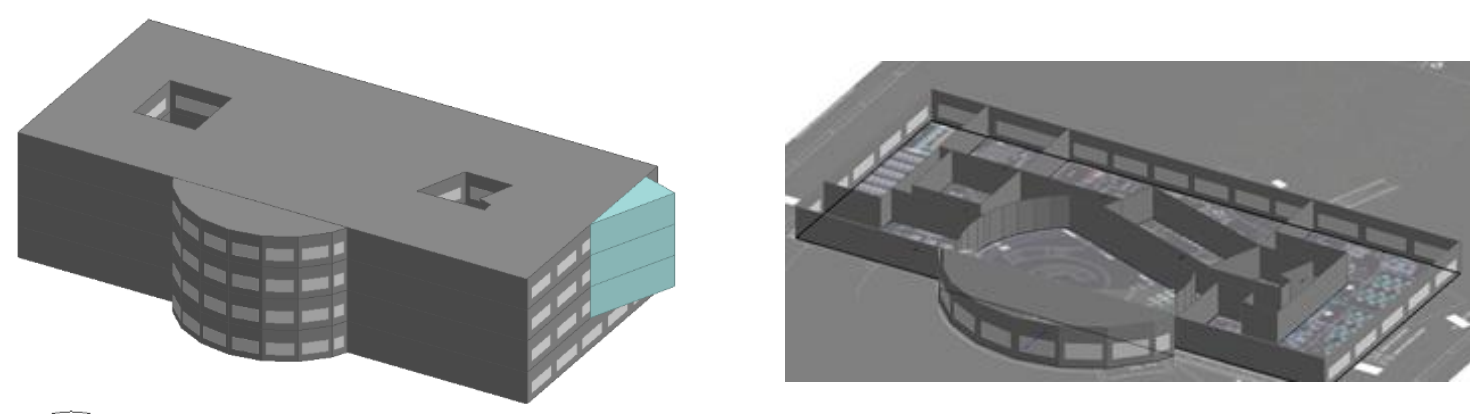

Table (3) Main characteristics of the analyzed building systems and climate

\begin{tabular}{|ll|}
\hline Building area & $7,300 \mathrm{~m}^{2}$ \\
\hline Window to wall ratio & $30 \%$ \\
\hline T summer set point & $24{ }^{\circ} \mathrm{C}$ \\
\hline Occupancy level & 0.11 person $/ \mathrm{m}^{2}$ \\
\hline Illumination level & $300 \mathrm{lux}$ \\
\hline Occupancy scheduling & From $9: 00$ am to $18: 00 \mathrm{pm} 5$ days/week \\
\hline
\end{tabular}

\section{RESULTS}

Figure (13) Base case Monthly Electric Consumption.

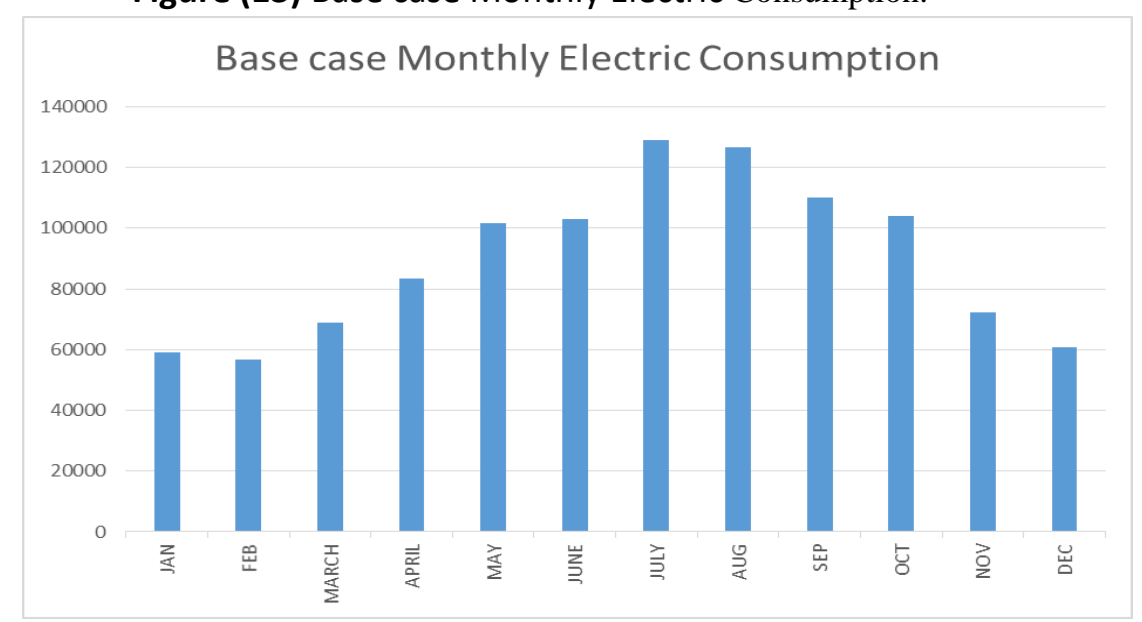

Table (4) Base case Monthly Electric Consumption.

\begin{tabular}{|l|l|l|l|l|l|l|l|l|l|l|l|l|l|}
\hline & JAN & FEB & MAR & $\begin{array}{l}\text { APRI } \\
\text { L }\end{array}$ & MAY & JUNE & JULY & AUG & SEP & OCT & NOV & DEC & $\begin{array}{l}\text { Tota } \\
\text { I }\end{array}$ \\
\hline $\begin{array}{l}\text { Elect } \\
\text { ricity }\end{array}$ & 5894 & 5668 & 6884 & 8339 & 1017 & 1028 & 1290 & 1268 & 1099 & 1040 & 7213 & 6081 & 107 \\
1.91 & 4.73 & 3.54 & 60.3 & 81.9 & 19.1 & 03.3 & 36.6 & 66.2 & 6.32 & 6.47 & $\begin{array}{l}528 \\
6\end{array}$ \\
\hline
\end{tabular}


Figure (14) Base case Monthly Electricity Break-down

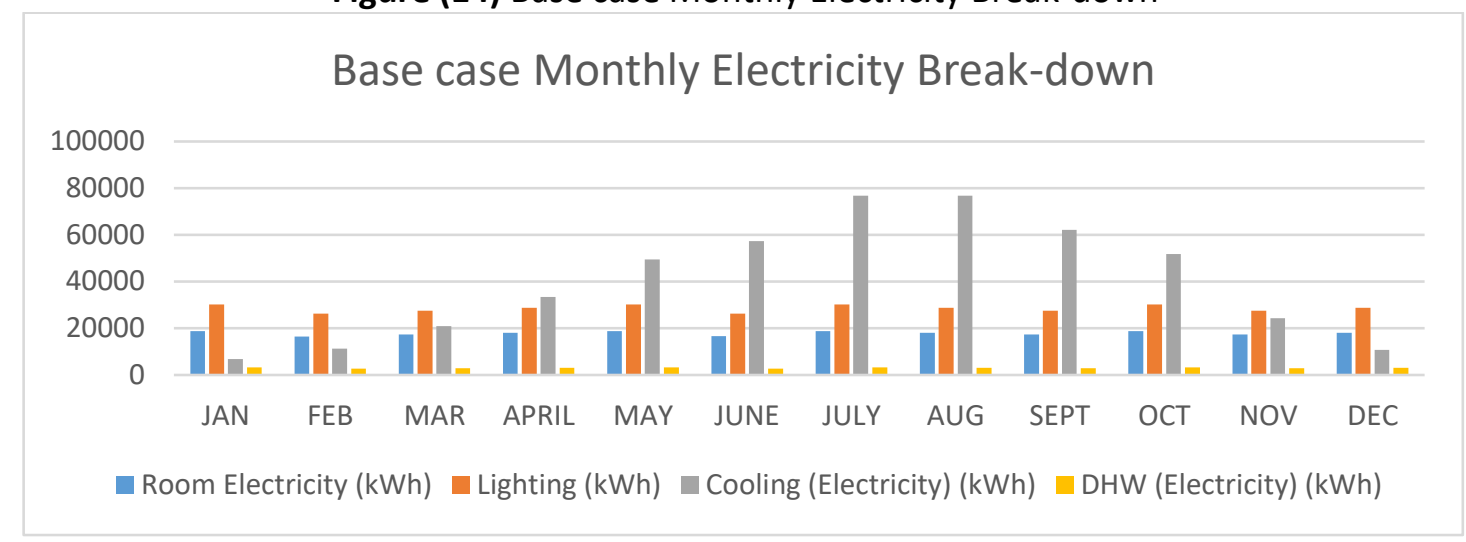

Table (5) Base case Monthly Electricity Break-down.

\begin{tabular}{|c|c|c|c|c|c|c|c|c|c|c|c|c|c|}
\hline & JAN & FEB & MAR & $\begin{array}{l}\text { APRI } \\
\mathrm{L}\end{array}$ & MAY & JUNE & JULY & AUG & SEPT & OCT & NOV & DEC & Total \\
\hline $\begin{array}{l}\text { Room } \\
\text { Electrici } \\
\text { ty } \\
\text { (kWh) }\end{array}$ & $\begin{array}{l}1882 \\
4.46\end{array}$ & $\begin{array}{l}1644 \\
7.82\end{array}$ & $\begin{array}{l}1739 \\
0.93\end{array}$ & $\begin{array}{l}1803 \\
2.25\end{array}$ & $\begin{array}{l}1882 \\
4.46\end{array}$ & $\begin{array}{l}1659 \\
8.72\end{array}$ & $\begin{array}{l}1882 \\
4.46\end{array}$ & $\begin{array}{l}1810 \\
7.7\end{array}$ & $\begin{array}{l}1731 \\
5.48\end{array}$ & $\begin{array}{l}1882 \\
4.46\end{array}$ & $\begin{array}{l}1731 \\
5.48\end{array}$ & $\begin{array}{l}1810 \\
7.7\end{array}$ & $\begin{array}{l}2146 \\
13.9\end{array}$ \\
\hline $\begin{array}{l}\text { Lighting } \\
\text { (kWh) }\end{array}$ & $\begin{array}{l}3015 \\
9.63 \\
\end{array}$ & $\begin{array}{l}2622 \\
5.76 \\
\end{array}$ & $\begin{array}{l}2753 \\
7.05 \\
\end{array}$ & $\begin{array}{l}2884 \\
8.34 \\
\end{array}$ & $\begin{array}{l}3015 \\
9.63\end{array}$ & $\begin{array}{l}2622 \\
5.76 \\
\end{array}$ & $\begin{array}{l}3015 \\
9.63 \\
\end{array}$ & $\begin{array}{l}2884 \\
8.34 \\
\end{array}$ & $\begin{array}{l}2753 \\
7.05 \\
\end{array}$ & $\begin{array}{l}3015 \\
9.63\end{array}$ & $\begin{array}{l}2753 \\
7.05 \\
\end{array}$ & $\begin{array}{l}2884 \\
8.34\end{array}$ & $\begin{array}{l}3422 \\
46.2 \\
\end{array}$ \\
\hline $\begin{array}{l}\text { Cooling } \\
\text { (Electri } \\
\text { city) } \\
\text { (kWh) }\end{array}$ & $\begin{array}{l}6756 . \\
86\end{array}$ & $\begin{array}{l}1122 \\
4.95\end{array}$ & $\begin{array}{l}2098 \\
8.06\end{array}$ & $\begin{array}{l}3344 \\
7.95\end{array}$ & $\begin{array}{l}4957 \\
1.86\end{array}$ & $\begin{array}{l}5727 \\
1.06\end{array}$ & $\begin{array}{l}7683 \\
0.72\end{array}$ & $\begin{array}{l}7678 \\
2.21\end{array}$ & $\begin{array}{l}6215 \\
8.36\end{array}$ & $\begin{array}{l}5187 \\
7.74\end{array}$ & $\begin{array}{l}2435 \\
8.1\end{array}$ & $\begin{array}{l}1079 \\
5.43\end{array}$ & $\begin{array}{l}4820 \\
63.3\end{array}$ \\
\hline $\begin{array}{l}\text { DHW } \\
\text { (Electr.( } \\
\text { kWh) }\end{array}$ & $\begin{array}{l}3204 . \\
32\end{array}$ & $\begin{array}{l}2786 . \\
37\end{array}$ & $\begin{array}{l}2925 . \\
69\end{array}$ & $\begin{array}{l}3065 . \\
01\end{array}$ & $\begin{array}{l}3204 . \\
32\end{array}$ & $\begin{array}{l}2786 . \\
37\end{array}$ & $\begin{array}{l}3204 . \\
32\end{array}$ & $\begin{array}{l}3065 . \\
01\end{array}$ & $\begin{array}{l}2925 . \\
69\end{array}$ & $\begin{array}{l}3204 . \\
32\end{array}$ & $\begin{array}{l}2925 . \\
69\end{array}$ & $\begin{array}{l}3065 . \\
01\end{array}$ & $\begin{array}{l}3636 \\
2.12\end{array}$ \\
\hline
\end{tabular}

Table (6) Base case Annual Electricity Break Down.

\begin{tabular}{|l|l|}
\hline & Electricity KWH \\
\hline Room Electricity (KWh) & 214613.9 \\
\hline Lighting (KWh) & 342246.2 \\
\hline Cooling (Electricity) (KWh) & 482063.3 \\
\hline Domestic Hot Water (DHW )(Electricity) (KWh) & 36362.12 \\
\hline
\end{tabular}

Energy consumption was analyzed After adding the following Energy Efficiency measures:

- Using renewable energy sources such installing $900 \mathrm{~m} 2 \mathrm{PV}$ panels on the building roof and a Central solar water heater.

- Using LED lights in the building to reduce the Electricity Consumption.

- Using Low-Emmissivity Double Glazing in the structure glazing to reduce the thermal effect.

- Using occupancy sensors to reduce electrical consumption.

The Annual Electric energy Consumption was reduced from 1,075 MWh to $561 \mathrm{MWh}$, making Reductions in Annual Energy Consumption of about $48 \%$.

Electric consumption in Lighting was reduced from $342 \mathrm{MWh}$ to $114 \mathrm{MWh}$ making reductions of $66.6 \%$

Cooling Load was reduced from $482 \mathrm{MWh}$ to $231 \mathrm{MWh}$ making reductions of $52 \%$ 
Table (7) Modified case Monthly Electric Consumption.

\begin{tabular}{|l|l|l|l|l|l|l|l|l|l|l|l|l|l|}
\hline & JAN & FEB & $\begin{array}{l}\text { MA } \\
\text { R }\end{array}$ & $\begin{array}{l}\text { APR } \\
\text { IL }\end{array}$ & $\begin{array}{l}\text { MA } \\
\text { Y }\end{array}$ & $\begin{array}{l}\text { JUN } \\
\text { E }\end{array}$ & $\begin{array}{l}\text { JUL } \\
\text { Y }\end{array}$ & $\begin{array}{l}\text { AU } \\
\text { G }\end{array}$ & $\begin{array}{l}\text { SEP } \\
\text { T }\end{array}$ & OCT & $\begin{array}{l}\text { NO } \\
\text { V }\end{array}$ & DEC & $\begin{array}{l}\text { Tot } \\
\text { al }\end{array}$ \\
\hline Electricity & 300 & 261 & 308 & 384 & 505 & 558 & 730 & 741 & 614 & 553 & 357 & 296 & 561 \\
(kWh) & 48. & 96. & 42. & 75. & 25. & 24. & 00. & 02. & 72. & 94. & 44. & 89. & 318 \\
& 91 & 94 & 28 & 5 & 11 & 65 & 94 & 72 & 25 & 5 & 86 & 8 & .5 \\
\hline $\begin{array}{ll}\text { Generation } \\
\text { (Electricity) }\end{array}$ & 143 & 167 & 225 & 234 & 257 & 235 & 233 & 228 & 221 & 205 & 156 & 135 & 244 \\
(kWh) & 51. & 04 & 93. & 83. & 40 & 69. & 20. & 50. & 17. & 01 & 51. & 12. & 375 \\
& 5 & & 6 & 6 & & 2 & 7 & 5 & 1 & & 9 & 1 & \\
\hline
\end{tabular}

Figure (15) Modified case Monthly Electric Consumption

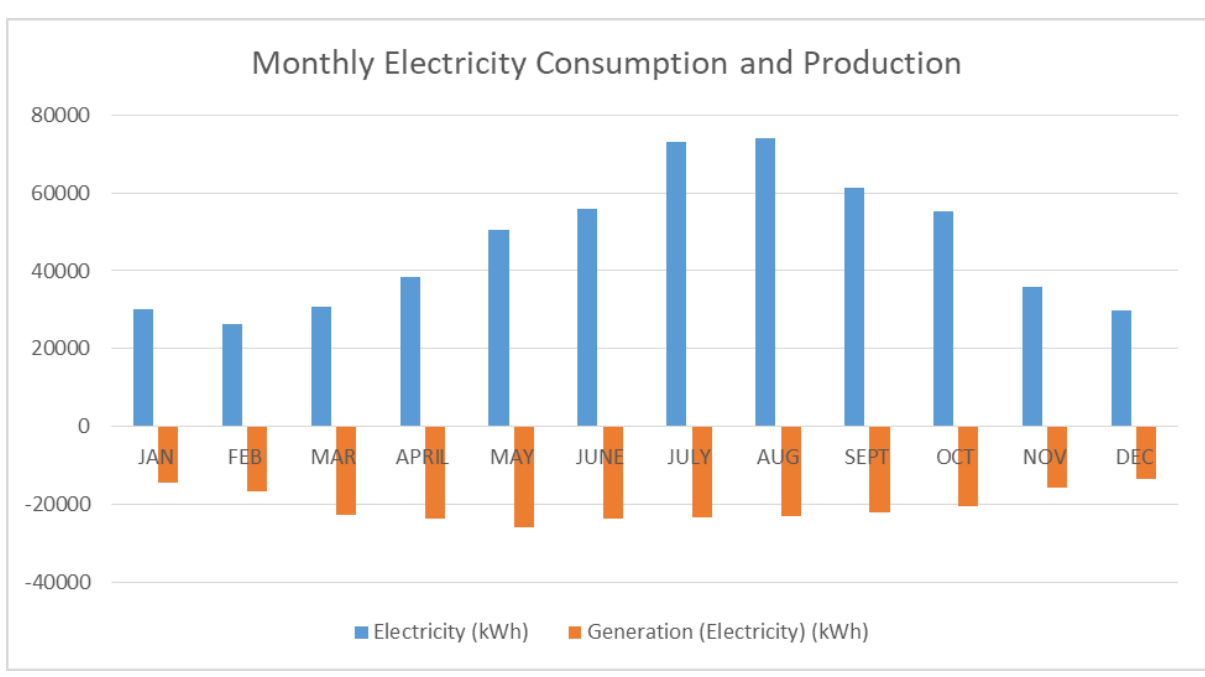

Table (8) Modified case Monthly Electricity Break Down

\begin{tabular}{|c|c|c|c|c|c|c|c|c|c|c|c|c|c|}
\hline & JAN & FEB & $\begin{array}{l}\text { MA } \\
\mathrm{R} \\
\end{array}$ & $\begin{array}{l}\text { APR } \\
\text { IL }\end{array}$ & $\begin{array}{l}\mathrm{MA} \\
\mathrm{Y}\end{array}$ & $\begin{array}{l}\text { JUN } \\
\mathrm{E}\end{array}$ & $\begin{array}{l}\text { JUL } \\
Y\end{array}$ & $\begin{array}{l}\mathrm{AU} \\
\mathrm{G}\end{array}$ & $\begin{array}{l}\text { SEP } \\
\mathrm{T}\end{array}$ & OCT & $\begin{array}{l}\text { NO } \\
\mathrm{V}\end{array}$ & DEC & $\begin{array}{l}\text { Tot } \\
\text { al }\end{array}$ \\
\hline $\begin{array}{l}\text { Room } \\
\text { Electricity } \\
\text { (kWh) }\end{array}$ & $\begin{array}{l}1882 \\
4.46\end{array}$ & $\begin{array}{l}1644 \\
7.82\end{array}$ & $\begin{array}{l}1739 \\
0.93\end{array}$ & $\begin{array}{l}1803 \\
2.25\end{array}$ & $\begin{array}{l}1882 \\
4.46\end{array}$ & $\begin{array}{l}1659 \\
8.72\end{array}$ & $\begin{array}{l}1882 \\
4.46\end{array}$ & $\begin{array}{l}1810 \\
7.7\end{array}$ & $\begin{array}{l}1731 \\
5.48\end{array}$ & $\begin{array}{l}1882 \\
4.46\end{array}$ & $\begin{array}{l}1731 \\
5.48\end{array}$ & $\begin{array}{l}1810 \\
7.7\end{array}$ & $\begin{array}{l}2146 \\
13.9\end{array}$ \\
\hline Lighting (kWh) & $\begin{array}{l}1120 \\
9.4\end{array}$ & $\begin{array}{l}9193 \\
.98\end{array}$ & $\begin{array}{l}9372 \\
.63\end{array}$ & $\begin{array}{l}9376 \\
.64\end{array}$ & $\begin{array}{l}9245 \\
.19\end{array}$ & $\begin{array}{l}7988 \\
.33\end{array}$ & $\begin{array}{l}9153 \\
.45\end{array}$ & $\begin{array}{l}8927 \\
.22\end{array}$ & $\begin{array}{l}8988 \\
.32\end{array}$ & $\begin{array}{l}1033 \\
7.65 \\
\end{array}$ & \begin{tabular}{|l|}
1002 \\
1.41 \\
\end{tabular} & \begin{tabular}{|l|l|}
1094 \\
4.36 \\
\end{tabular} & $\begin{array}{l}1147 \\
58.6 \\
\end{array}$ \\
\hline $\begin{array}{l}\text { Cooling } \\
\text { (Electricity) } \\
(\mathrm{kWh})\end{array}$ & $\begin{array}{l}15.0 \\
5\end{array}$ & $\begin{array}{l}555 . \\
13\end{array}$ & $\begin{array}{l}4078 \\
.71\end{array}$ & $\begin{array}{l}1106 \\
6.61\end{array}$ & $\begin{array}{l}2245 \\
5.46\end{array}$ & $\begin{array}{l}3123 \\
7.6\end{array}$ & $\begin{array}{l}4502 \\
3.03\end{array}$ & $\begin{array}{l}4706 \\
7.81\end{array}$ & $\begin{array}{l}3516 \\
8.44\end{array}$ & $\begin{array}{l}2623 \\
2.39\end{array}$ & $\begin{array}{l}8407 \\
.97\end{array}$ & $\begin{array}{l}637 . \\
75\end{array}$ & $\begin{array}{l}2319 \\
46\end{array}$ \\
\hline $\begin{array}{l}\text { Generation } \\
\text { Electr(kWh) }\end{array}$ & $\begin{array}{l}1433 \\
1.5\end{array}$ & $\begin{array}{l}1670 \\
4\end{array}$ & $\begin{array}{l}2259 \\
3.6\end{array}$ & $\begin{array}{l}2348 \\
3.6\end{array}$ & $\begin{array}{l}2574 \\
0\end{array}$ & $\begin{array}{l}2356 \\
9.2\end{array}$ & $\begin{array}{l}2332 \\
0.7\end{array}$ & $\begin{array}{l}2285 \\
0.5\end{array}$ & $\begin{array}{l}2211 \\
7.1\end{array}$ & $\begin{array}{l}2050 \\
1\end{array}$ & $\begin{array}{l}1565 \\
1.9\end{array}$ & $\begin{array}{l}1351 \\
2.1\end{array}$ & $\begin{array}{l}2443 \\
75\end{array}$ \\
\hline
\end{tabular}


Figure (16) Modified case Monthly Electricity Break Down

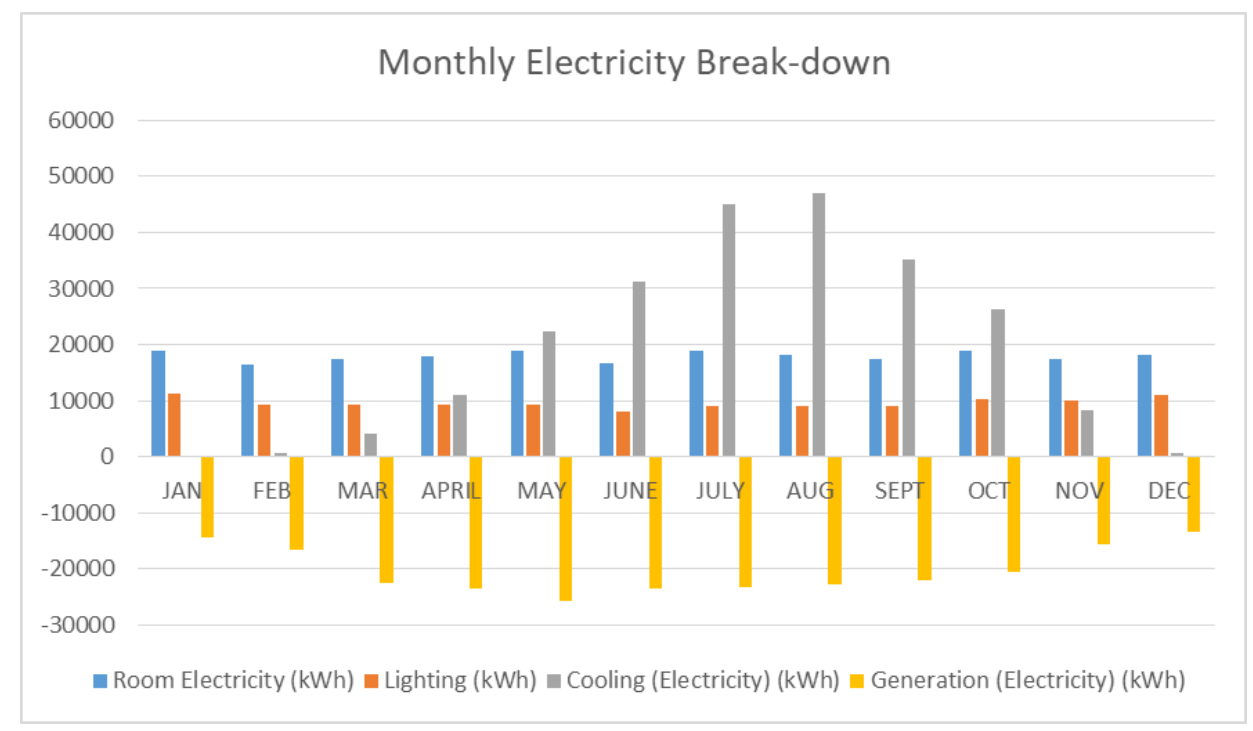

Table (9) Modified case Annual Fuel Break Down.

\begin{tabular}{|l|l|}
\hline & Consumption(KWh) \\
\hline Room Electricity (KWh) & 214613.9 \\
\hline Lighting (KWh) & 114758.6 \\
\hline Cooling (Electricity) (KWh) & 231946 \\
\hline Generation (Electricity) (KWh) & 244375 \\
\hline
\end{tabular}

The Annual electricity production due to the installation of $900 \mathrm{~m} 2 \mathrm{PV}$ Panels on the building roof is $244.38 \mathrm{MWH}$ which covers about $40 \%$ from the building Energy consumption.

Figure (17) Roof top PV application

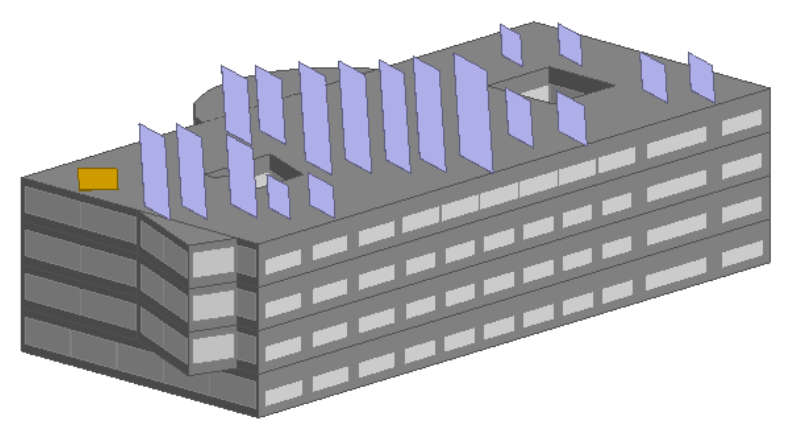

Figure (18) Reductions in Lighting, Cooling load and total consumption. 


\section{Electricity Consumption reductions}

\section{0}

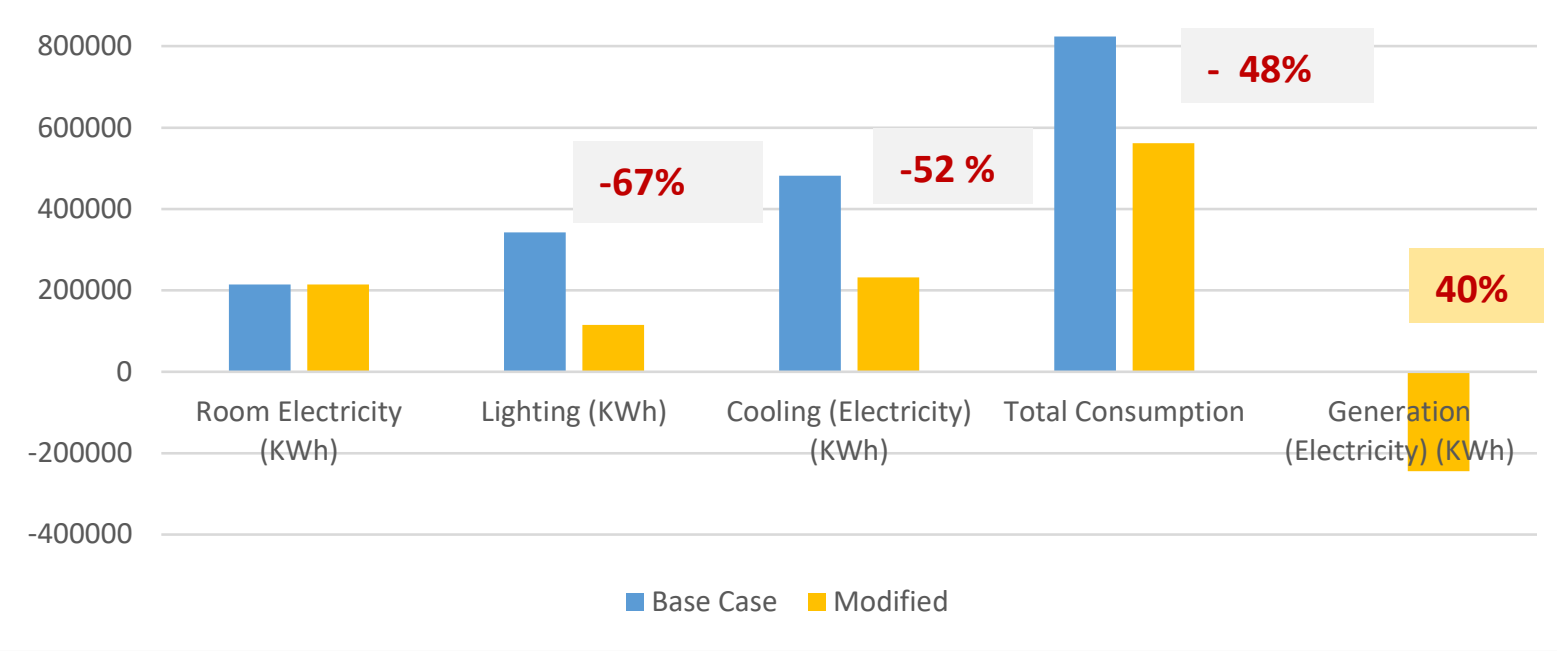

Table (10) Reductions in Lighting, Cooling load and total consumption.

\begin{tabular}{|l|l|l|}
\hline & Base Case & Modified \\
\hline Room Electricity (KWh) & 214613.92 & 214613.92 \\
\hline Lighting (KWh) & 342246.22 & 114758.58 \\
\hline Cooling (Electricity) (KWh) & 482063.28 & 231945.95 \\
\hline Total Consumption & 824309.5 & 561318.45 \\
\hline Generation (Electricity) (KWh) & 0 & -244375.14 \\
\hline
\end{tabular}

\section{CONCLUSIONS}

- By investigating the current status of RE and particularly PV applications in Egypt, it could be observed that the government has put policies and ambitious plans to enhance the PV applications, yet there is still a need for more comprehensive plans to encourage investors and stack-holders to apply PV applications. Subsidies and incentives can contribute greatly to lower the cost and thus enhance PV applications.

- This research examines the effect of applying Energy Efficiency measures and roof top application of PV modules on energy consumption in an air-conditioned office building in Egypt. Annual Energy reductions was calculated by means of Energy Plus, a reliable Energy simulation software. The annual energy production due to the PV roof top installation was calculated as well. Also, the energy requirements for cooling, and lighting was evaluated.

- It was proven that the Annual Electric energy Consumption was reduced from 1,075 MWh to $561 \mathrm{MWh}$, making Reductions in Annual Energy Consumption of about $\quad 48 \%$. Electric consumption in Lighting was reduced from 342 to 114 making reductions of $67 \%$ and Cooling Load was reduced from 482 to 231 making reductions of $52 \%$. 
- The Annual electricity production due to the installation of $900 \mathrm{~m} 2$ PV Panels on the building roof is $244.38 \mathrm{MWH}$ which covers about $40 \%$ from the building Energy consumption.

- It could be concluded that adopting an integrated methodology for applying Energy Efficiency measures and PV application offers a good opportunity to solve the Energy problems and could contribute significantly in reducing the total building energy consumption.

\section{References}

Abdin,A., et all, (2006), Energy Effeciency in the construction sector in the Mediterrenean: Mrket analysis and capacity assessment-Egypt. Study released under the MED-ENEC. Project.http://medenec.com/en/TOPIC/market studies/ Market analysis and capacity assessment-Egypt.pdf

Akker, J.V. (2010). Energy Efficiency Improvement and Greenhouse Gas Reduction project. United Nation Development Program, Egypt.

Bloem, J. J., Colli, A., \& Strachan, P. (2005). Evaluation of PV technology implementation in the building sector. In Proceedings of international conference of passive and low energy cooling for the built environment Santorini, Greece.

Bloem, J. J. (2008). Evaluation of a PV-integrated building application in a well-controlled outdoor test environment. Building and Environment, 43(2),205-216.

Biyik, E.,et all, (2017),A Key Review of Building Integrated Photovoltaic (BIPV) Systems. Engineering Science and Technology, an International Journal , 20, 833-858. https://doi.org/10.1016/j.jestch.2017.01.009

CIBSE, Energy Efficiency in Buildings: CIBSE Guide F, Chartered Institution of Building Services Engineers, London, 2004.

DOE, Buildings Energy Data Book, Office of Energy Efficiency and Renewable Energy, U.S. Department of Energy, Washington, DC, USA, 2010.

Eiffert P. and Kiss J. G., (2000). Building-Integrated Photovoltaic. Designs for Commercial and Institutional Structures. A Sourcebook for Architects. Springfield: Us Department of Commerce

Egyptian Electricity Holding Company (2016/2017). Annual Report 2016, 2017. Egyptian Electricity Holding Company, Cairo. http://www.moee.gov.eg/english new/EEHC Rep/2018.pdf

Ghazali A, , Haw L,(2017), Performance and financial evaluation of various photovoltaic vertical facades on high-rise building in Malaysia, Energy and Buildings, 134.

Hu Du, Huang P, Jones P,(2019), Modular facade retrofit with renewable energy technologies: The definition and current status in Europe, Energy and Buildings,205. Hermstad K. ( 2006). Architectural Integration of PV in Norwegian Office Buildings. Research made for Norwegian Research Council.

Hwang T, Kang S, Kim J T(2012). Optimization of the building integrated photovoltaic system in office buildings-Focus on the orientation, inclined angle and installed area. Energy and Buildings;46:92-104.

IEA ECBCS Annex 53, Annex 53 Total Energy Use in Buildings: Analysis \& Evaluation Methods, www.ecbcsa53.org

IEA, PVPS Report, "Task 7 - potential of building integrated photovoltaics", 2001. Research, 3, 1251-1259.

International Energy Agency (2011) World Energy Outlook. OECD, France. https://doi.org/10.1787/weo-2011-en.

International Energy Agency, Worldwide Trends in Energy Use and Efficiency, Authoring Institution: International Energy Agency (IEA), Head of Communication and Information 
Office,

Paris,

France,

2008, http://www.iea.org/publications/freepublications/publication/Indicators 2008 1.pdf.

Kaldellis, J., Kavadias, K., \& Zafirakis, D. (2012). Experimental validation of the optimum photovoltaic panels' tilt angle. Renewable Energy, 46, 179-191.

Karkanias, C.,et all,(2010). Energy efficiency in the Hellenic building sector: An assessment of the restrictions and perspectives of the market. Energy Policy, 38(6).

Kazim, (2007) Assessments of primary energy consumption and its environmental consequences in the United Arab Emirate, Renewable and Sustainable Energy Reviews 11 (2007) 426-446.

K.Y. Foo,(2015).A vision on the opportunities, policies and coping strategies for the energy security and green energy development in Malaysia..Renewable and Sustainable Energy Reviews 51 (2015) 1477-1498

L. Pérez-Lombard, J. Ortiz, C. Pout, A review on buildings energy consumption information, Energy and Buildings 40 (2008) 394-398.

Meggers, F., Leibundgut, H., Kennedy, S., Qin, M., Sclaich, M., \& Sobek, W. (2012).Reduce CO2from buildings with technology to zero emissions. Sustainable Cities and Society, 2(1), 29-36.

M. Kayfeci, A. Kecebas, E. Gedik (2013), Determination of optimum insulation thickness of external walls with two different methods in cooling applications, Appl. Therm. Eng. 50 217 e224.

NREA (New \& Renewable Energy Authority), (2018). Ministry of Electricity \& Renewable Energy Annual Report 2018, Cairo.

N.V. Baker (2009), The Handbook of Sustainable Refurbishment: Non-domestic Buildings, Earthscan, London, UK.

O. Kaynakli, A review of the economical and optimum thermal insulation thickness for building applications, Renewable and Sustainable Energy Reviews 16 (2012) 415-425.

Peng, Ch., Huang, Y., \& Wu, Z. (2011). Building-integrated photovoltaics (BIPV) in architectural design in China. Energy and Buildings, 43, 3592-3598.

Papantoniou Sotiris, Tsoutsos Theocharis. (2008). "Building integrated PV application in the island of Crete". 23rd European Photovoltaic Solar Energy Conference Proceedings

Randall,Thomas.,Fordham,Max., Photovoltaics and Architecture(London: Spon Press,2003).

Salem, T. and Kinab, E. (2015),Analysis of Building-Integrated Photovoltaic Systems: A Case Study of Commercial Buildings under Mediterranean Climate. Procedia Engineering, 118, 538-545. https://doi.org/10.1016/j.proeng.2015.08.473

Vourdoubas,J., (2018), Use of Renewable Energies for the Creation of Net Zero Carbon Emission Residential Buildings in Northern Greece, Open Journal of Energy Efficiency, 7.

World Bank (2010) Egypt: Improve Energy Efficiency. Sustainable Development Department (MNSSD) Middle East and North Africa Region, Egypt.

Youssef A M A, Zhai Z J, Reffat R M (2015). Design of optimal building envelopes with integrated photovoltaics. Build Simul-China;8(3):353-366. 